\title{
Advances in the Interpretation of Tomographic Images as an Early Detection Method of Oil Palm Affected by Basal Stem Rot in Colombia
}

\author{
M. Arango, G. Martínez, and G. Torres, Pests and Diseases Program, Colombian Oil Palm Research Centre, Cenipalma. Bogota, Colombia
}

\begin{abstract}
Arango, M., Martínez, G., and Torres, G. 2016. Advances in the interpretation of tomographic images as an early detection method of oil palm affected by basal stem rot in Colombia. Plant Dis. 100:1559-1563.

Basal stem rot, one of the most important diseases of oil palm in Southeast Asia, has also been identified in Colombia. The increase in disease incidence in the last decade has attracted the attention of producers and researchers. In the search for a procedure that allows for the early identification of diseased palm, Cenipalma evaluated the use of electrical impedance tomography to identify the different stages of development of basal stem rot. The tomograms were compared with transversal sections of healthy and diseased oil palm trees. Following Cenipalma's preliminary studies on early diagnosis of basal stem rot with tomography, the present study improved upon the technique by analyzing the tomograms of 209

diseased palm trees (confirmed by symptomatology), 346 asymptomatic palm trees, and 132 healthy palm trees. The minimum and maximum electric impedance values as well as the ratio between these values was recorded. The range of 1 to $95 \Omega$ was used to represent the internal damage. The ratios averaged 5.1 for diseased, 1.9 for asymptomatic, and 1.5 for healthy palm trees. With the range and the ratio criteria established, it was possible to identify the disease in $100 \%$ of asymptomatic sampled palm trees. This study demonstrated that electrical impedance tomography is a powerful tool for early detection of basal stem rot, which can be used to establish an early disease management program.
\end{abstract}

Oil palm (Elaeis guineensis Jacq.) is one of the most important crops in Colombia, with more than 500,000 ha planted, and is the largest producer of oil palm in the Americas (Mesa 2013). Basal stem rot (BSR), caused by Ganoderma spp., has been ignored because it was observed at low frequency; however, Martínez (2011) considered that the increasing number of new cases of BSR in the region signifies a serious threat for the oil palm industry in Colombia. Due to the recent accelerated increase in disease incidence, it was considered one of the top three most important diseases of oil palm in Colombia, after bud rot (Phytophthora palmivora) and lethal wilt (causal agent unknown).

In Malaysia and Indonesia, BSR is the most important disease of oil palm (Singh 1995). According to Meon (2005), in these production areas, palm tree losses exceeded $85 \%$ where palm trees were over 25 years old. Traditionally, diseased palm trees are diagnosed by external symptoms. These symptoms have been described as accumulation of spear leaves, wilting of green fronds hanging downward like a "skirt," yellowing of younger leaves, and reduction in size of the fronds (Chung 2011; Turner 1981). One of the limitations with this detection method is that external symptoms are only expressed when the internal damage exceeds $50 \%$ of the trunk diameter (Turner 1981). Detection by this method not only is unreliable but also reduces chances of intervention with the affected palm trees (Hushiarian et al. 2013; Turner 1981).

The appearance of lesions inside the stem base is typical and allows diagnosis to be made in the absence of pathogen fructification (Turner 1981). There is a dry rot of the internal tissue with a yellow transitional area between healthy and diseased tissue (Turner 1981). Later in the development of the disease, it is possible to observe the signs of the disease with the formation of a typical bracket-shaped basidiocarp of Ganoderma spp. with a shiny upper surface and

Corresponding author: G. Torres; E-mail: gtorres@ cenipalma.org

Dr. Gerardo Martínez sadly passed away in 2015, during the writing of this article

Accepted for publication 2 February 2016.

http://dx.doi.org/10.1094/PDIS-12-15-1473-RE

(C) 2016 The American Phytopathological Society distinctive whitish border (Turner 1981). Similar external and internal symptoms have been observed in Colombia (Mestizo et al. 2012; Nieto 1994, 1995; Pineda and Martínez 2010; Tovar and Nieto 1998).

The fruiting bodies of Ganoderma spp. have also been observed in the base of the stem and, occasionally, in the roots close to the stem (Mestizo et al. 2012).

According to Singh (1995) and Mazliham et al. (2008), some structures of Ganoderma spp. remain as saprophytes on decaying stumps or roots left in the ground and constitute the first path of infection when they contact new plantings. In contrast, Ariffin et al. (2000), Flood et al. (2003), and Rees et al. (2009) noted that, despite the large number of basidiospores produced by the fungus, the ways in which the disease is spread are not clear.

Hushiarian et al. (2013) suggested that there are few tools that enable the identification of infected palm trees in the early stages of development. Utomo and Niepold (2000) and Toh Choon et al. (2012) considered that molecular techniques together with other methods used to identify the presence of ergosterol in tissues of infected plants have shown progress in the early diagnosis of BSR. However, the high costs of investment and low availability of technicians restricts the use of these methods under field conditions.

Electrical impedance tomography was recently evaluated for detecting internal rot in forest trees (Bieker and Rust 2010). The methodology consists of delivering electrical impulses through the tissue to detect any change in impedance through the tissue where the impulse is applied (Brown 2003).

The purpose of this study was to evaluate the electrical impedance tomography technique as a tool for early diagnosis of oil palm trees affected with BSR in oil-palm-growing regions in Colombia.

\section{Materials and Methods}

Location of the study. This study was carried out in two oil palm production areas in Colombia: the Mid-Magdalena Valley (Central Zone) and the Caribbean region (Northern Zone). The oil palm estates Indupalma, Palmeras de la Costa, Maraquilla, and Buenavsta were selected for the study, because all had a history of the disease on palm trees that exceeded 13 years old. In total, 478 apparently healthy and 209 diseased palm trees (symptomatic) were used in the study.

Equipment and image construction techniques. The electrical impedance tomograph PiCUS Treetronic (Argus Electronic 2010) was used during the study. In total, 12 nails were placed radially 


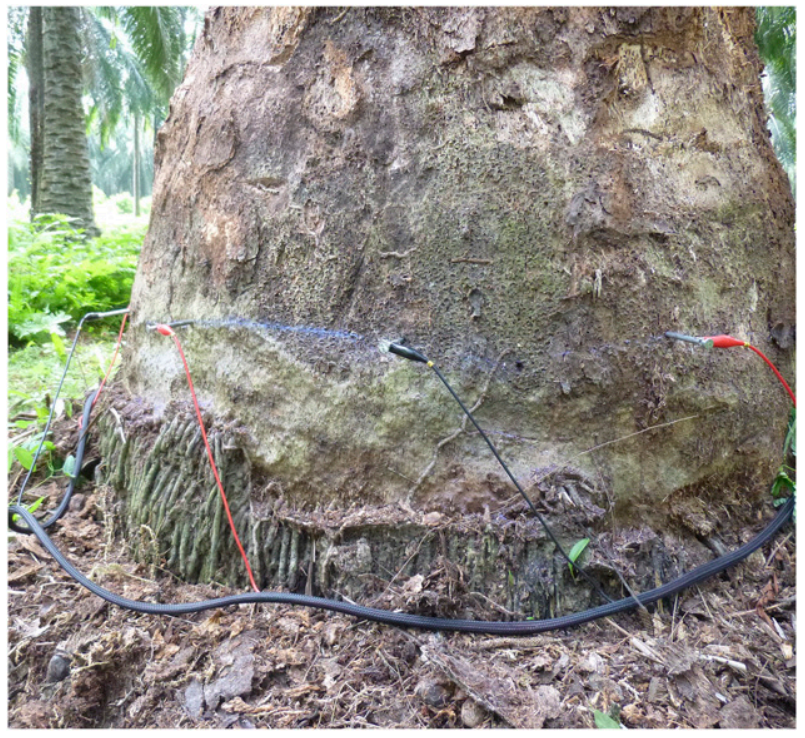

Fig. 1. Installation of sensors in a palm tree for tomographic measurements. equidistant at $15 \mathrm{~cm}$ above the soil level as probes. In order to place the nails, the basal petioles below $20 \mathrm{~cm}$ from the soil were removed and the nails were placed at a $3-\mathrm{cm}$ depth. Individual wires connected to electrodes in the equipment were attached to each nail with an electrical clip to create the electrical field (Fig. 1).

The electric current used for the tomographies was automatically set by the equipment following the manufacturer's recommendation. The tree location was recorded following the row-palm positioning system normally used in the crop. In addition to this information, the distance between the probes (nails) and their height from ground line were recorded. In total, 687 tomographies were conducted.

Each palm tree with macroscopic symptoms was cut down at the tomography level and a photo was obtained of the sections. The pictures were compared with the image produced by the tomograph. In total, 42 palm trees that showed internal damage with the tomograph but were visually classified as healthy were classified as asymptomatic; these trees were also cut and photographed. In addition, 10 healthy palm trees that did not show any internal damage with the tomograph were cut to corroborate the absence of internal damage. The healthy tissue was also photographed.

Data generated by the tomograph was downloaded using the PiCUS Q73 software (Argus Electronic). The parameters of the

\section{Diseased Palm}
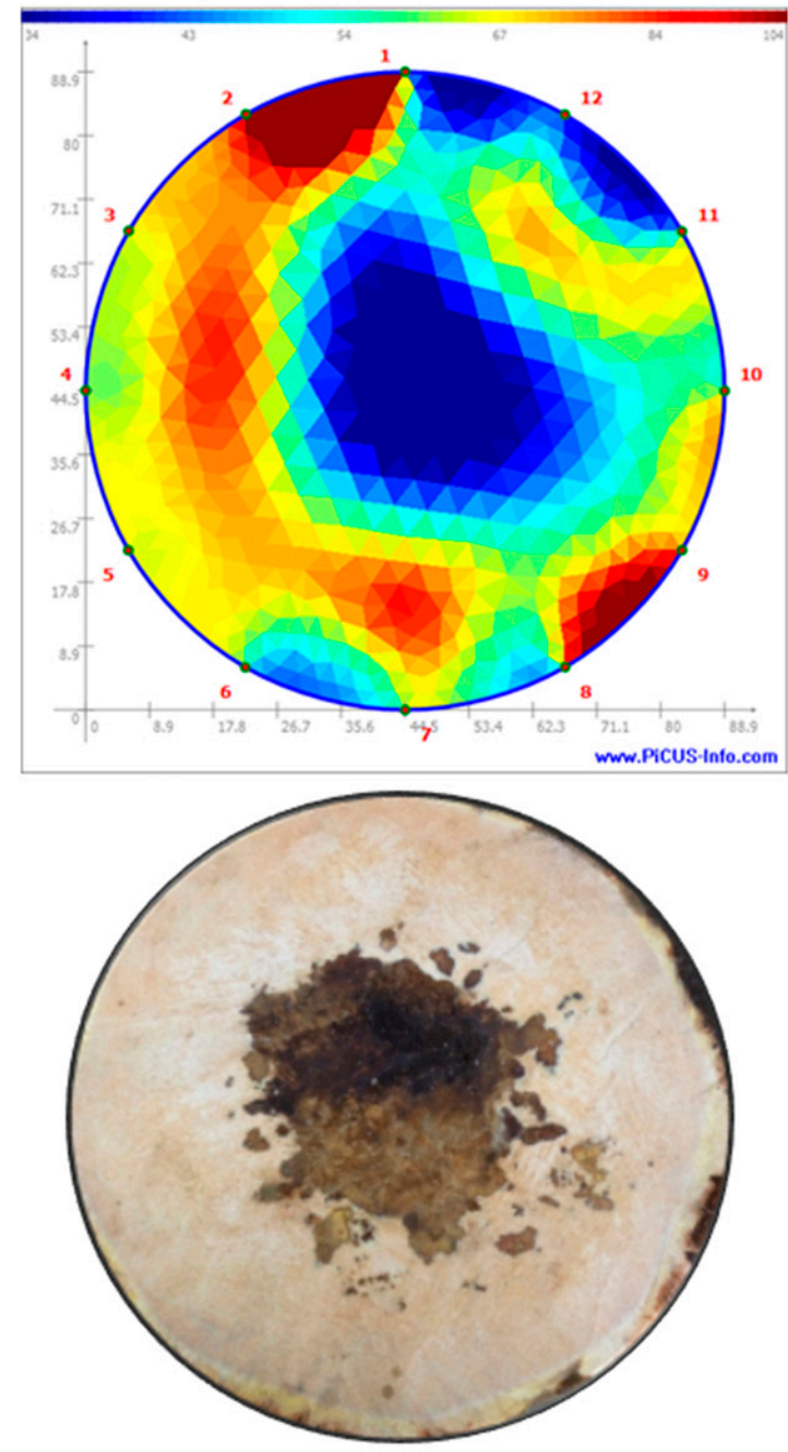

\section{Healthy Palm}
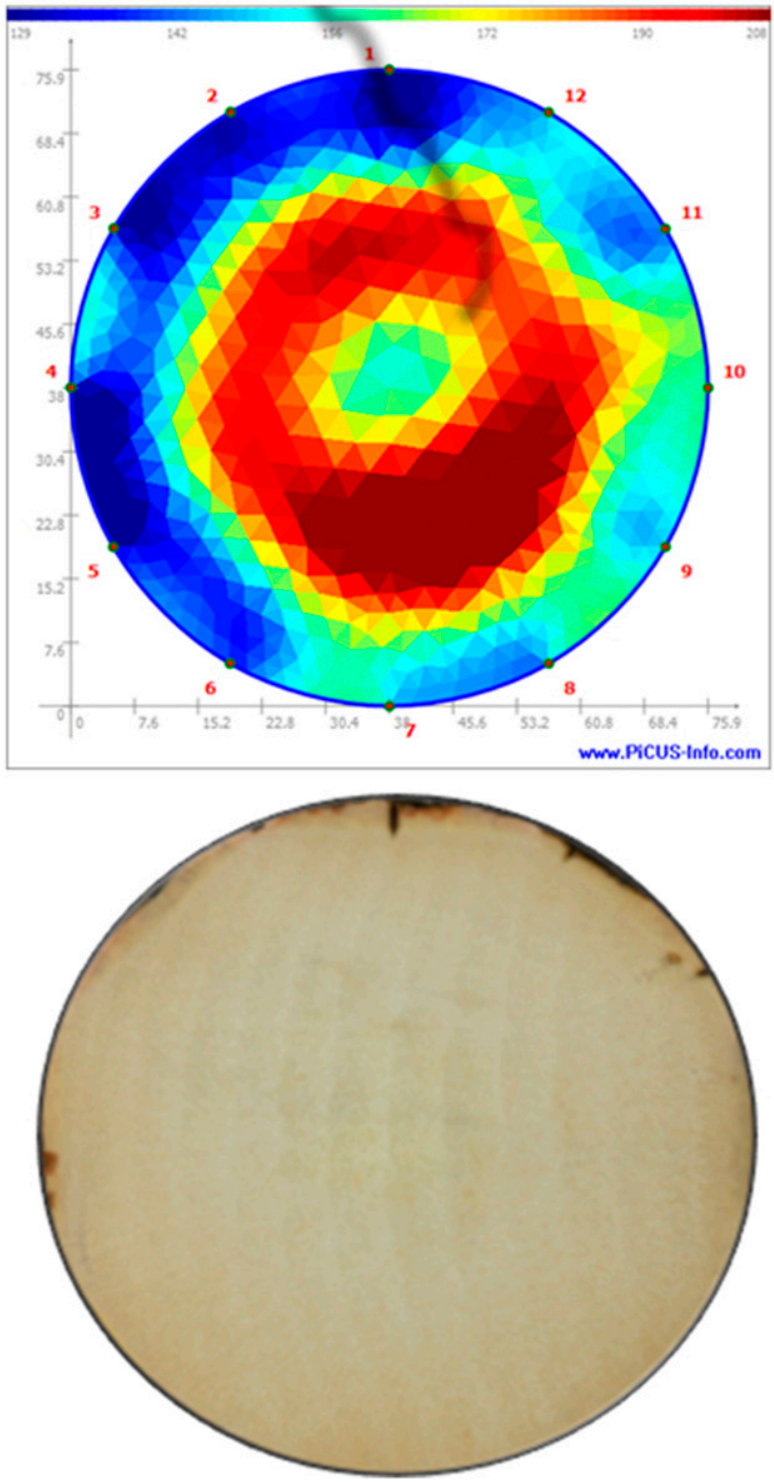

Fig. 2. Tomographs (top row) and photographs (bottom row) of sections from a palm tree infected by basal stem rot disease and a healthy palm. Blue tones represent low impedance values (in ohms), while red tones indicate high impedance. Green and yellow tones represent intermediate impedance values. 


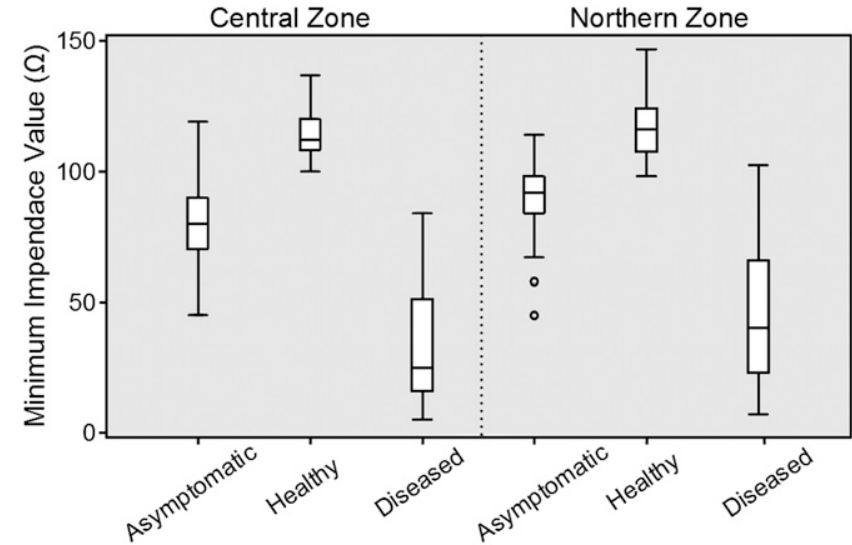

Fig. 3. Range of minimum impedance value in ohms $(\Omega)$ of the tomographs corresponding to asymptomatic, healthy, and diseased palm trees in the Central and North Zones. software were modified to obtain a better resolution and to reduce variation between the maximum and minimum impedance level. Preliminary tests indicated that the Smoothness and Fineness parameters should be set to 20 and 8 , respectively, to obtain a good quality image.

The interpretation of each one of the tomograms was done using minimum and maximum values of electric impedance, as well as the ratio between them. Additionally, the maximum impedance value of each tomography was analyzed within the range of 65 to $110 \mathrm{ohms}$ $(\Omega)$, in order to establish which accurately represented the presence of lesions in the palm under study.

Data analysis. All statistical analyses were performed using R (version 3.2.1; R Foundation for Statistical Computing). Data were subjected to one-way analysis of variance. Maximum and minimum impedance values and the quotient between them were used as response variables for the analyses. Healthy, asymptomatic, and diseased categories were used as independent variables. Tukey's least significant difference test $(P=0.05)$ was performed for separation of means when significant differences were obtained.

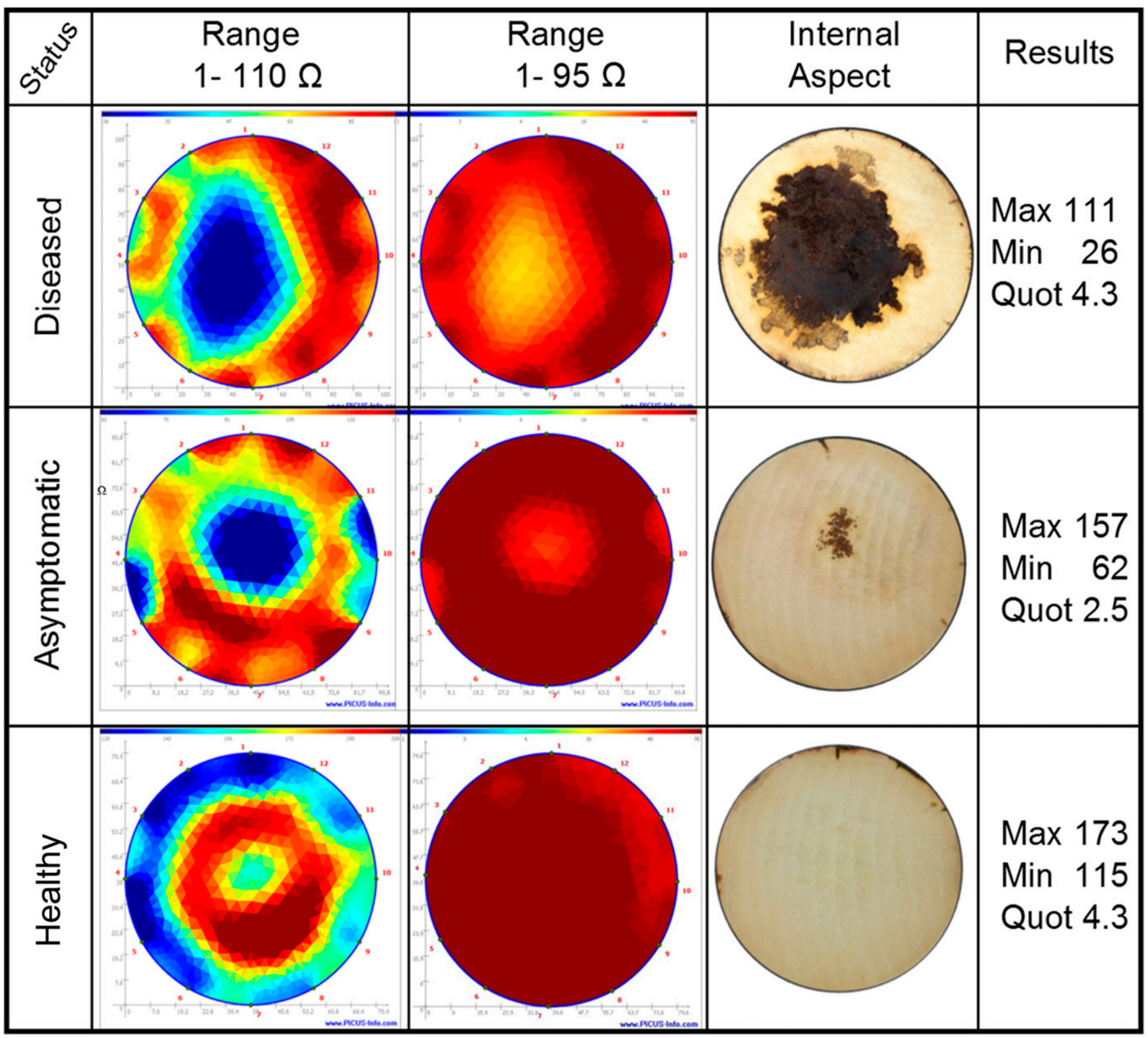

Fig. 4. Comparison of tomographies taken at a range of 1 to 110 and 1 to 95 ohms $(\Omega)$ with the internal observed damage. Maximum (Max) and minimum (Min) impedance value in $(\Omega)$, with the ratio value obtained between them, are presented in the right column. Blue tones represent low impedance values, while red tones indicate high impedance. Green and yellow tones represent intermediate values. 


\section{Results}

In total, 687 tomograms were processed from apparently healthy and diseased palm trees. A graphical impedance color representation was done for each individual tree. The colors represented the values of electrical impedance in $\Omega$ produced in each tomogram; blue tints indicated low electrical impedance values, whereas red colors showed high impedance values. Green and yellow colors represented the values in between (Fig. 2).

The variables minimum electric impedance and the ratio between maximum and minimum values (Fig. 3) were statistically different for each one of the healthy, asymptomatic, and diseased palm groups. The variable of maximum impedance value was similar for all groups. Among the studied high impedance ranges (65 to $110 \Omega$ ), tomographies analyzed at 1 to $95 \Omega$ presented the best representation of the internal damage of affected palm trees. The use of higher limits (e.g., $110 \Omega$ ) resulted in false positives, while lower values (e.g., $65 \Omega$ ) resulted in false negatives. Values higher or lower than $95 \Omega$ were not useful for the correct identification of affected palm trees (Fig. 4). The results were consistent in all the studied regions.

With the selected range of 1 to $95 \Omega$, this technique detected that 346 of the 555 apparently healthy palm trees actually had some internal damage. The healthy tissue was indicated in the tomography with a dark red color, while the infected tissue was indicated in light red and yellow colors (Fig. 4). A dissection of 43 of these asymptomatic palm trees confirmed the presence of the disease at the same point and severity indicated by the tomography. The 209 tomograms of palm trees with macroscopic symptoms of BSR showed an intense red color for the less affected area. The lowest impedance values of the infected palm trees was $39 \Omega$, and was registered at the points where the palm trees were severely affected by the disease (Table 1).

The ratio between the maximum and minimum impedance value of the tomographies was statistically different between the healthy, asymptomatic, and diseased palm trees. In the healthy palm trees, the average value for the two areas was 1.5; the average was 1.9 for asymptomatic palm trees and 5.1 for the palm trees with advanced stages of disease development (Table 1).

The coefficients of variation for minimum impedance value and the ratio between higher and lower impedance values were, on average, four times higher in diseased than in healthy palm trees.

Table 1. Range of maximum (Max) and minimum (Min) electric impedance values and ratio between these values in healthy, asymptomatic, and diseased palm trees from the Mid-Magdalena Valley (Central Zone) and the Caribbean (North Zone) regions in Colombia

\begin{tabular}{|c|c|c|c|c|c|c|c|}
\hline Condition & $n^{\mathbf{a}}$ & Zone & Variable $^{\mathbf{b}}$ & $\begin{array}{c}\text { Mean } \\
(\Omega)\end{array}$ & $\begin{array}{c}\operatorname{Min} \\
(\Omega)\end{array}$ & $\begin{array}{c}\operatorname{Max} \\
(\boldsymbol{\Omega})\end{array}$ & $\mathrm{CV}^{\mathrm{c}}$ \\
\hline \multirow[t]{6}{*}{ Healthy } & \multirow[t]{3}{*}{92} & \multirow[t]{3}{*}{ North } & Min & 116.7 & 98.0 & 147.0 & 10.0 \\
\hline & & & $\operatorname{Max}$ & 181.4 & 135.0 & 239.0 & 14.5 \\
\hline & & & Ratio & 1.6 & 1.2 & 2.0 & 11.1 \\
\hline & \multirow[t]{3}{*}{40} & \multirow[t]{3}{*}{ Central } & Min & 114.6 & 100.0 & 137.0 & 8.3 \\
\hline & & & $\operatorname{Max}$ & 173.1 & 116.0 & 229.0 & 12.2 \\
\hline & & & Ratio & 1.5 & 1.2 & 1.9 & 11.8 \\
\hline \multirow[t]{6}{*}{ Asymptomatic } & \multirow[t]{3}{*}{57} & \multirow[t]{3}{*}{ North } & Min & 90.5 & 45.0 & 114.0 & 14.3 \\
\hline & & & $\operatorname{Max}$ & 160.4 & 98.0 & 263.0 & 24.0 \\
\hline & & & Ratio & 1.8 & 1.1 & 3.1 & 26.0 \\
\hline & \multirow[t]{3}{*}{289} & \multirow[t]{3}{*}{ Central } & Min & 80.2 & 45.0 & 119.0 & 17.0 \\
\hline & & & $\operatorname{Max}$ & 157.5 & 81.0 & 255.0 & 17.6 \\
\hline & & & Ratio & 2.0 & 1.3 & 4.0 & 26.4 \\
\hline \multirow[t]{6}{*}{ Diseased } & \multirow[t]{3}{*}{51} & \multirow[t]{3}{*}{ North } & Min & 45.0 & 7.0 & 102.0 & 56.5 \\
\hline & & & $\operatorname{Max}$ & 134.5 & 80.0 & 299.0 & 33.1 \\
\hline & & & Ratio & 4.0 & 1.4 & 15.3 & 64.8 \\
\hline & \multirow[t]{3}{*}{158} & \multirow[t]{3}{*}{ Central } & Min & 34.0 & 5.0 & 84.0 & 64.2 \\
\hline & & & $\operatorname{Max}$ & 153.7 & 40.0 & 292.0 & 29.0 \\
\hline & & & Ratio & 6.3 & 1.5 & 16.5 & 56.8 \\
\hline
\end{tabular}

\footnotetext{
${ }^{\mathrm{a}}$ Number of palm trees sampled.

b Variables used here are minimum impedance value in ohms $(\Omega)$, maximum impedance value in ohms, and the ratio between these values.

${ }^{\mathrm{c}}$ Coefficient of variation.
}

The average of minimum electric impedance for asymptomatic palm trees was $27 \%$ lower than that observed in healthy palm trees; however, it was 53\% higher than on diseased trees (Table 1). For the ratio between the limits, the asymptomatic palm trees presented a value $18 \%$ higher than healthy palm trees and $63 \%$ lower than diseased palm trees (Table 1).

\section{Discussion}

The present study demonstrates the benefits of using electric impedance tomography in oil palm for early diagnosis of BSR. In both symptomatic and healthy-papering tomographs, it was possible to differentiate between healthy and diseased tissue represented as a spectrum of colors. However, it was critical to consider the minimum and maximum impedance values, as well as the ratio between them, to determine which range was optimal (1 to $95 \Omega$ ) to represent the internal status of the palm trees.

Brown (2003) described that impedance is directly affected by how a tissue is constituted. The high variability of the coefficient of variation of the minimum impedance value and quotient for symptomatic and asymptomatic palm trees could be explained by the changes in water content of the tissue and by the great variability in the size of the lesions in the trees affected by BSR. It was evident that some palm trees were in earlier stages of infection when others were in more advanced stages, affecting the impedance measurement.

Turner (1981) stated that, by the time that external symptoms are expressed, more than $50 \%$ of the trunk base has been affected. This was confirmed in the present study with the tomographies. The ability to diagnose asymptomatic palm trees is a great advancement in oil palm disease management and not only will permit the reduction in inoculum by earlier eradication of the affected palm trees but also will provide researchers with tools to evaluate earlier management practices such as fungicide treatment.

We recommended further studies to evaluate this methodology on palm trees that do not present macroscopic symptoms and which are located in areas with history of BSR in order to develop procedures to escalate the use of this tool in the management and control of BSR of oil palm in Colombia.

\section{Acknowledgments}

This article is dedicated to memory of Dr. Gerardo Martínez, who created, managed, and looked for the resources to execute this study. We thank all of the staff in the states in the North and Central Zones, where this work was developed; L. Göcke, official of Argus Electronic GmbH, for his support in the interpretation of tomographic images; E. Mesa for her invaluable assistance in the statistical analysis of the data collected in this study; A. Nail for her critical review of the manuscript; and the Colombian Oil Palm Fund, the Colombian Oil Palm Research Centre (Cenipalma), and the Colombian Learning Service for their support in the development of this work.

\section{Literature Cited}

Argus Electronic. 2010. PiCUS OilPalmTronic: Electrical Impedance Tomograph for Trees. Argus Electronic GmbH, Rostock, Germany.

Ariffin, D., Idris, A., and Singh, G. 2000. Status of Ganoderma in oil palm. Page 49-68 in: Ganoderma Diseases of Perennial Crops. J. Flood, P. Bridge, and M. Holderness, eds. CAB International, Wallingford, UK.

Bieker, D., and Rust, S. 2010. Non-destructive estimation of sapwood and heartwood width in Scots pine (Pinus sylvestris L.). Silva Fenn. 44:267273.

Brown, B. H. 2003. Electrical impedance tomography (EIT): A review. J. Med. Eng. Technol. 27:97-108.

Chung, G. F. 2011. Management of Ganoderma diseases in oil palm plantations. Plant. Kuala Lumpur 87:325-339.

Flood, J., Hagan, Y., and Foster, H. 2003. Enfermedades de la palma de aceite causadas por Ganoderma: Una interpretación de la investigación de la Estación Bah Lias. Palmas 24:9-30.

Hushiarian, R., Yusof, N. A., and Wada Dutse, S. 2013. Detection and control of Ganoderma boninense: Strategies and perspectives. SpringerPlus 2:555.

Martínez, G. 2011. Avances en el manejo Sanitario de la Palma de Aceite. Palmas 32:87-99.

Mazliham, M., Loonis, P., and Idris, A. 2008. Interpretation of sound tomography image for the recognition of Ganoderma infection level in oil palm. Pages 409-422 in: Trends in Intelligent Systems and Computer Engineering. O. Castillo, X. Li, and S. L. Ao, eds. Springer, New York. 
Meon, S. 2005. Potencial del manejo biológico de la pudrición basal del tallo en palma de aceite: Problemas, retos y restricciones. Palmas 26:41-54.

Mesa, J. 2013. Palabras del Presidente Ejecutivo de Fedepalma, Jens Mesa Dishington. Palmas 34:49-54.

Mestizo, Y., Bandera, G., Aya, H., Sarria, G., Varón, F., Navia, M., and Martínez, G. 2012. Caracterización de síntomas e identificación de microorganismos en palmas de aceite afectadas por la Pudrición basal del estípite. Palmas 33:13-27.

Nieto, L. E. 1994. Pudrición basal del tallo de la palma de aceite (Elaeis guineensis Jacq.) causada por Ganoderma sp. Palmas 15:31-38.

Nieto, L. E. 1995. Incidencia de pudriciones de estípite de la palma de aceite (Elaeis guineensis Jacq.) en Colombia. Palmas 16:227-232.

Pineda, B., and Martínez, G. 2010. Reconocimiento de enfermedades en la palma de aceite. Tecnologías para la agroindustria de la palma de aceite: Guía para facilitadores. Fedepalma, Bogotá, Colombia.
Rees, R. W., Flood, J., Hasan, Y., Potter, U., and Cooper, R. M. 2009. Basal stem rot of oil palm (Elais guineensis); mode of root infection and lower stem invasion by Ganoderma boninense. Plant Pathol. 58:982-989.

Singh, G. 1995. Pudrición basal de estípite de palma de aceite en Malasia. Palmas 16:233-251.

Toh Choon, R. L., Sariah, M., and Mariam Siti, M. N. 2012. Ergosterol from the soilborne fungus Ganoderma boninense. J. Basic Microbiol. 52:608-612.

Tovar, J., and Nieto, L. 1998. Caracterización de las principales pudriciones de estípite de la palma de aceite (Elaeis guineensis Jacq.), en la Zona Norte de Colombia. Palmas 19:45-52.

Turner, P. D. 1981. Oil Palm Diseases and Disorders. Oxford University Press, Kuala Lumpur, Malaysia.

Utomo, C., and Niepold, F. 2000. Development of diagnostic methods for detecting Ganoderma-infected in oil palms. J. Phytopathol. 148:507514 